\title{
Total Bakteri pada Berbagai Umur dan Lokasi Peternakan Sapi Bali di Nusa Penida
}

(TOTAL BACTERIA IN VARIOUS AGES AND LOCATIONS OF BALI CATTLE IN NUSA PENIDA)

\section{Putu Chyntia Nirmalasari Mantrawan ${ }^{1 *}$, I Nengah Kerta Besung ${ }^{2}$, I Gusti Ketut Suarjana ${ }^{2}$, Ni Ketut Suwiti ${ }^{3}$}

${ }^{1}$ Praktisi Dokter Hewan Kabupaten Klungkung Bali. ${ }^{2}$ Laboratorium Mikrobiologi Veteriner Fakultas Kedokteran Hewan, Universitas Udayana, Denpasar, Bali. ${ }^{3}$ Pusat Kajian Sapi Bali Universitas Udayana.

*Email: tia_chyntia11@yahoo.com

\begin{abstract}
ABSTRAK
Penelitian ini bertujuan untuk mengetahui total bakteri yang diisolasi dari feses sapi bali pada berbagai umur dan lokasi peternakan. Sampel yang digunakan adalah feses sapi bali sebanyak 24 sampel yang ditumbuhkan pada media Nutrient Agar dengan metode tuang. Penelitian ini menggunakan Rancangan Acak Kelompok (RAK) pola faktorial; lokasi peternakan yaitu dataran tinggi dan dataran rendah dan tiga tingkatan umur (pedet, dara, dewasa). Data total bakteri diuji dengan Uji Beda Nyata Terkecil (BNT). Hasil penelitian menunjukkan total bakteri pada feses sapi dewasa sebanyak 724,6250 x10 $\mathrm{CFU} / \mathrm{g}$ ) lebih tinggi dibandingkan sapi dara sebanyak 667,5000 x10 $\mathrm{CFU} / \mathrm{g}$ ) dan sapi pedet sebanyak 499,5000 x10 $\mathrm{CFU} / \mathrm{g}$ ). Jumlah total bakteri pada sapi yang dipelihara di dataran tinggi sebanyak $629,4167 \times 10^{9} \mathrm{CFU} / \mathrm{g}$ ) yang tidak menunjukkan perbedaan nyata dengan yang dipelihara di dataran rendah sebanyak 631,6667 x $10^{9} \mathrm{CFU} / \mathrm{g}$.
\end{abstract}

Kata kunci: Sapi bali; Nusa Penida; total bakteri

\section{ABSTRACT}

This study aims were to determine the total number of bacteria isolated from bali cattle feces at various ages and locations of farms. As many as 24 cattle fecal samples were examined on Nutrient Agar medium using the casting method. This study used a Randomized Complete Block Design of $2 \mathrm{x}$ 3 factorial consisted of two different farm locations (highland and lowland) and three levels of cattle maturity (calves, heifers, adult). The total bacteria were analyzed using Analysis of Variance and continued with Least Significant Difference Test. The results showed that the total number bacteria isolated from adult $724.6250 \times 10^{9} \mathrm{CFU} / \mathrm{g}$ higher than heifers $667.5000 \times 10^{9} \mathrm{CFU} / \mathrm{g}$ and calf 499.5000 $\mathrm{x} 10^{9} \mathrm{CFU} / \mathrm{g}$. Total number of bacteria isolated from feces from highland $629.4167 \times 10^{9} \mathrm{CFU} / \mathrm{g}$ which did not show significant difference compared to bali cattle from lowland $631.6667 \times 10^{9} \mathrm{CFU} / \mathrm{g}$.

Keywords: Bali cattle; Nusa Penida; total bacteria

\section{PENDAHULUAN}

Sapi bali (Bos sondaicus) merupakan salah satu bangsa sapi asli Indonesia yang merupakan keturunan asli banteng (Bibos banteng) dan telah mengalami proses domestikasi yang terjadi sebelum 3.500 SM (Jimmy, 2014). Sapi bali menyebar di Indonesia yaitu di Sulawesi Selatan, Bali, Nusa Tenggara Timur, Nusa Tenggara Barat, Sulawesi Selatan, Sulawesi Utara, Gorontalo, Kalimantan Selatan, Sulawesi Tenggara, Sulawesi Barat dan Lampung (Talib, 2002).
Dinas Peternakan dan Kesehatan Hewan Propvinsi Bali bekerja sama dengan Universitas Udayana melakukan verifikasi bibit sapi bali dengan menggunakan Surat Kelayakan Layak Bibit (SKLB) untuk bibit sapi bali yang memenuhi persyaratan kualitatif dan kuantitatif. Diharapkan bibit sapi bali yang berasal dari Nusa Penida akan berkualitas baik dari sisi performa maupun kesehatannya.

Nusa Penida merupakan daerah terpisah dari dataran Pulau Bali. Daerah ini 
dijadikan sumber bibit dan pemurnian sapi bali, karena sapi yang ada di Nusa Penida ini bebas dari penyakit ternak, seperti penyakit JD (Jembrana Disease) dan SE (Septicemia Epizootica). Pemberlakuan peraturan yang ketat terhadap lalu lintas ternak, yaitu dilarangnya sapi luar untuk memasuki ke wilayah tersebut.

Secara normal di dalam tubuh sapi terdapat berbagai jenis mikroba. Mikroba ini terdapat di dalam saluran nafas, saluran pencernaan dan kulit luar. Bakteri yang umumnya ditemukan dalam feses hewan ruminansia diantaranya Lactobacillus $s p$, Eubacterium, Propionibacterium, Streptococcus, Bacteroides, Selenomonas, Metanobacterium, Clostridium, Butyvibrio, dan Escherichia coli (Hidayati, 2010).

Umumnya variasi kandungan bakteri tersebut dalam saluran pencernaan sapi di pengaruhi oleh tingkat umur ternak, jenis pakan dan kandungan gizi pada pakan. Berdasarkan tingkat umur, sapi bali dapat di golongkan menjadi tiga kategori yaitu sapi pedet, dara, dan dewasa. Sapi yang termasuk dalam golongan pedet adalah sapi yang baru lahir sampai berusia 8 bulan sedangkan sapi yang termasuk golongan dara yaitu sapi yang berkisaran 9 bulan sampai 3 tahun dan belum pernah beranak. Sedangkan sapi bali yang termasuk golongan dewasa merupakan sapi bali yang sudah pernah melahirkan yang berumur sekitar tiga tahun keatas (Suwandi, 1997).

Jumlah bakteri pada saluran pencernaan juga dipengaruhi oleh cara pemeliharaan seperti pembersihan kandang yang rutin serta pakan yang diberikan. Galyean dan Tedeschi (2014) dan Jost et al (2013) menyatakan bahwa ada hubungan antara pakan yang diberikan dengan total bakteri pada saluran cerna. Di Nusa Penida air sangat sulit ditemukan keadaan tersebut menyebabkan sapi bali dipelihara dalam keadaan sanitasi yang jelek, kandang yang kotor feses bercampur dengan urine, sehingga menjadi sumber kontaminasi dan dapat menyebabkan penyakit. Kotoran atau feses merupakan salah satu sumber cemaran mikroba yang berasal dari saluran pencernaan (Debor at al., 2014). Maka dari itu meningkatnya jumlah bakteri yang melebihi kapasitas dalam saluran pencernaan akan berakibat buruk bagi pertumbuhan sapi tersebut (Suardana et al., 2009).

Deteksi jumlah kuman pada saluran pencernaan sapi merupakan hal yang penting. Mengetahui populasi mikroba pada saluran pencernaan ini dapat menggambarkan tingkat kesehatan ternak, gangguan proses pencernaan, dan memberikan gambaran adanya infeksi. Populasi total bakteri pada feses sapi di Amerika sebanyak $37-49 \times 10^{9} \mathrm{CFU} / \mathrm{g}$ (Aschemann et al., 2013), sedangkan sapi yang dipelihara di Burkina Faso sebanyak $35 \times 10^{8}$ sel bakteri (Kagambèga et al., 2013). Sejauh ini belum pernah dilaporkan jumlah total bakteri pada feses sapi bali di Bali, khususnya Nusa Penida.

\section{METODE PENELITIAN}

\section{Materi Penelitian}

Penelitian ini menggunakan 24 sampel feses segar sapi bali betina yang terdiri atas sapi pedet, sapi dara, dan sapi dewasa. Sampel diambil dari dataran tinggi di Desa Sekartaji dan dataran rendah di Desa Kutampi Kaler, Nusa Penida, Kabupaten Klungkung.

\section{Metode Penelitian}

Pengambilan feses segar diambil sekitar $10 \mathrm{~g}$ dengan cara usap atau palpasi rektal dan dimasukan ke dalam tabung plastik yang diberi tutup. Sampel kemudian disimpan ke dalam boks yang berisis es untuk selanjutnya diperiksa di laboratorium.

\section{Analisis Data}

Menurut Fardiaz (1992), untuk mendapatkan jumlah koloni per gram feses menggunakan rumus koloni (X): $X=\frac{1}{\text { Pengenceran } x \text { Vol tanam }} C F U / g$ 
Data total bakteri dari sapi berdasarkan tingkat kedewasaan dan perbedaan ketinggian menggunakan Rancangan Acak Kelompok (RAK) pola faktorial. Selanjutnya, data dianalisis dengan Analysis of Variance (ANOVA) untuk menentukan ada atau tidaknya perbedaan dari beberapa perlakuan. Sebelum dianalisis, data ditransformasi ke dalam log Y. jika perlakuan menunjukkan perbedaan yang nyata, analisis dilanjutkan dengan uji Beda Nyata Terkecil (BNT) (Sampurna dan Nindhia, 2008).

\section{HASIL DAN PEMBAHASAN}

Hasil Penelitian perbandingan total bakteri feses sapi bali di Nusa Penida menurut tingkat umur dan dataran yang berbeda terhadap 24 sampel, didapatkan total bakteri yang berbeda setiap pemeriksaanya. Data total bakteri pada dataran tinggi dan dataran rendah pada berbagai umur disajikan pada tabel (Tabel $1)$.

Tabel 1. Rerata total bakteri feses sapi bali di Nusa Penida menurut tingkatan umur dan tinggi rendah dataran pemeliharaan.

\begin{tabular}{ccccccc}
\hline \multicolumn{5}{c}{ Tipe pemeliharaan $\left(10^{9} \mathrm{CFU} / \mathrm{g}\right)$} \\
\hline \multirow{3}{*}{ Ulangan } & Pedet & Dara & Dewasa & Pedet & Dara & Dewasa \\
1 & 696 & 596 & 892 & 484 & 736 & 411 \\
2 & 548 & 444 & 736 & 556 & 940 & 970 \\
3 & 524 & 420 & 724 & 384 & 856 & 622 \\
4 & 436 & 592 & 972 & 368 & 756 & 470 \\
\hline Rataan & 551 & 513 & 831 & 448 & 822 & 618 \\
\pm SD & \pm 107 & \pm 94 & \pm 121 & \pm 132 & \pm 94 & \pm 250 \\
\hline
\end{tabular}

Berdasarkan Tabel 1 dapat diketahui bahwa rerata jumlah total bakteri pada sapi pedet $551 \times 10^{9} \pm 107 \mathrm{CFU} / \mathrm{g}$; pada sapi dara $513 \times 10^{9} \pm 94 \mathrm{CFU} / \mathrm{g}$ dan pada sapi dewasa $831 \times 10^{9} \pm 121 \mathrm{CFU} / \mathrm{g}$. Sedangkan pada dataran tinggi yaitu berturut-turut pada sapi pedet $448 \times 10^{9} \pm 132 \mathrm{CFU} / \mathrm{g}$; pada sapi dara $822 \times 10^{9} \pm 94 \mathrm{CFU} / \mathrm{g}$ dan pada sapi dewasa $618 \times 10^{9} \pm 250 \mathrm{CFU} / \mathrm{g}$.

Analisis statistik menunjukkan bahwa perbandingan tiap kelompok umur tidak menunjukkan perbedaan nyata terhadap jumlah total bakteri. Begitu juga dengan lokasi peternakan yang tidak menunjukkan perbedaan nyata. Namun, perbedaan yang nyata terdapat pada jumlah total bakteri terhadap umur sapi. Total bakteri pada sapi dewasa nyata lebih tinggi dibandingkan dengan sapi dara maupun pedet.

Hasil dari analisis sidik ragam menunjukkan bahwa tinggi rendahnya dataran tidak berpengaruh terhadap jumlah total bakteri. Hal ini dikarenakan sistem pemeliharaan dan pakan yang diberikan relatif sama pada sapi antara dataran rendah di Desa Kutampi Kaler dan dataran tinggi di Desa Sekartaji. Keberadaan mikroba dalam saluran pencernaan membantu proses pencernaan atau fermentasi pakan yang masuk kedalam tubuh (Endang, 2014). Makin tinggi variasi pakan yang dimakan, maka makin meningkat jumlah bakteri yang ada di saluran pencernaan. Kondisi geografis di Nusa Penida hampir sama dan sangat jarang turun hujan, baik di dataran tinggi maupun dataran rendah. Kondisi ini berdampak pada sumber pakan sapi bali. Pada musim kering ketersedian pakan sapi terbatas, sebaliknya pada musim hujan ketersediaan pakan sapi lebih bervariasi mulai dari rumput-rumputan sampai berbagai tanaman. Karena terbatasnya curah hujan, maka pakan sapi di dataran tinggi maupun di dataran rendah hampir sama.

Sapi pedet hanya memperoleh pakan berupa air susu dari induknya. Sapi ini 
belum memakan dedaunan maupun rumput-rumputan. Air susu kaya akan gizi dan di dalam saluran pencernaan akan diserap secara sempurna. Kandungan gizi pada air susu, seperti: karbohidrat, protein, lemak dan mineral akan diserap di dalam usus halus, sehingga kemungkinan besar zat-zat pakan yang diteruskan ke usus besar memiliki kandungan gizi rendah. Rendahnya kandungan gizi pada usus besar berdampak pada menurunnya pertumbuhan kuman.

Sapi dara sudah mulai memakan dedaunan dan rumput-rumputan. Pakan ini akan diproses di dalam rumen dan kandungan gizi seperti karobohidrat, protein, lemak dan mineral akan diserap di dalam usus halus. Bahan pakan yang tidak bisa dicerna secara enzymatis di dalam rumen akan diteruskan ke usus besar untuk proses pencernaan secara mikrobiologis. Proses pencernaan secara mikrobiologis di dalam usus besar akan berpengaruh terhadap tingginya kandungan gizi pada usus besar tersebut.

Begitu juga dengan sapi dewasa, proses pencernaan secara enzymatik di dalam rumen dan secara mikrobiologis di dalam usus besar sudah lebih sempurna. Pakan yang tidak bisa dicerna di dalam rumen akan diteruskan ke dalam usus besar untuk proses pencernaan mikrobiologis, sehingga berdampak pada tingginya kandungan gizi pada usus besar. Tinggi rendahnya kandungan gizi pada usus besar sangat berpengaruh terhadap populasi mikroba. Makin tinggi kandungan gizi di dalam usus besar, makin meningkat jumlah mikrobanya (Soetanto, 2011).

\section{SIMPULAN DAN SARAN}

\section{Simpulan}

Berdasarkan hasil penelitian yang dilakukan, dapat disimpulkan bahwa total bakteri sapi bali dewasa di Nusa Penida lebih tinggi dibandingkan sapi pedet dan sapi daranya dan tidak ada perbedaan total bakteri pada sapi bali yang dipelihara di dataran tinggi maupun dataran rendah di wilayah tersebut.

\section{Saran}

Perlu dilakukan penelitian lebih lanjut tentang jenis bakteri yang ada di dalam feses sapi bali. Disamping itu, perlu juga diteliti lebih lanjut tentang hubungan unsur hara dalam tanah dengan kandungan unsur hara pada pakan sapi di Nusa Penida.

\section{UCAPAN TERIMAKASIH}

Penulis mengucapkan terima kasih kepada staf Laboratorium Mikrobiologi FKH Unud dan semua pihak yang turut membantu dalam proses penelitian, terutama Rektor atas Hibah Dana Invensi Universitas Udayana tahun 2015.

\section{DAFTAR PUSTAKA}

Aschemann M, Lebzien P, Joergensen RG, Sundrum A. 2013. Microbial biomass in feces of dairy cows affected by a nitrogen deficient diet. Arch. Anim. Nutr. 67(2): 104-108.

Debor KH, Mariana N, Jacob N, Nathan GF, Katipana. 2014 Pengaruh Probiotik Terhadap Kemampuan Cerna Mikroba Rumen Sapi Bali (The Effects of Probiotics on The Performances of Bali Cattle Rumen Microbial). $J$. Peternakan Sriwijaya. 3(1): 25-36.

Endang P, Edy R, Wayan SD, Christina MSL, Retno A. 2014 Karakteristik Cairan Rumen, Jenis, dan Jumlah mikrobia dalam rumen sapi. Bul. Peternakan. 38(1): 21-26.

Fardiaz S. 1992. Mikrobiologi Paangan I. PT Gramedia Pustaka Utama, Jakarta.

Galyean ML, Tedeschi LO. 2014. Predicting microbial protein synthesis in beef cattle: relationship to intakes of total digestible nutrients and crude protein. J. Anim. Sci. 92(11): 50995111.

Hidayati AY, Harlina E, Marlina T. 2010. Deteksi Jumlah Bakteri Total dan Koliform pada Lumpur Hasil Ikutan Pembentukan Gasbio Dari Feses Sapi. J. Ilmu Ternak. 10(1): 17-20.

Jimmy CT, Makalew A, Salendu AH, Endoh KM. 2014. Analisis Keuntungan Pemeliharaan Ternak Sapi 
di Kecamatan Sulun Tarenan Kabupaten Minahasa Selatan. $J$. Zootek. 34(2): 18-26.

Jost DI, Aschemann M, Lebzien P, Joergensen RG, Sundrum A. Microbial biomass in faeces of dairy cows affected by a nitrogen deficient diet. Arch. Anim. Nutr. 67(2): 104-108.

Kagambèga A, Lienemann $\mathrm{T}$, Aulu L, Traoré AS, Barro N, Siitonen A, Haukka K. 2013. Prevalence and characterization of Salmonella enterica from the feces of cattle, poultry, swine and hedgehogs in Burkina Faso and their comparison to human Salmonella isolates. BMC. Microbiol. 11(13): 253.

Sampurna IP, Nindhia TS. 2008. Analisis Data dengan SPSS. Udayana University Press. Denpasar
Soetanto. 2011. Mikrobiologi Rumen. Bahan Kuliah Nutrisi Ruminansia. Jurusan Nutrisi dan Makanan Ternak Fakultas Peternakan Universitas Brawijaya, Malang.

Suardana IW, Hendratno, IGMK, Hendratno B, Sumiarto, Lukman, DW. 2009. Deteksi Produksi Toksin Stx-1 dan Stx-2 dari Escherichia coli O157:H7 Isolat Lokal Hasil Isolasi Feses dan Daging Sapi. J. Vet. 10(4): 189-193.

Suwandi. 1997. Peranan mikroba rumen pada ternak ruminansia. Balai Penelitian Ternak Ciawi. Bogor

Talib C. 2002. Sapi Bali Di Daerah Sumber Bibit dan Peluang Pengembangannya. Bul. Teknik dan Pengembangan Peternakan. 12(3): 100-107. 